Vol. 7, No. 1, 2017

\title{
ASSESSMENT OF BALANCE RELIABILITY IN LOCAL ELECRTIC SYSTEM WITH ALTERNATIVE RENEWABLE SOURCES OF ENERGY
}

\author{
Petro Lezhniuk, Viacheslav Komar, Serhiy Kravchuk \\ Vinnytsia National Technical University, Vinnytsia \\ lpd@inbox.ru,kvo76@mail.ru,w1_1992@mail.ru
}

(C) Lezhniuk P., Komar V., Kravchuk S., 2017

Abstract: The research suggests a solution of the actual problem of analyzing the instability of generation of renewable sources of energy (RSE), in particular, solar power plants (SPP). The impact of instable RSE generation on the power balance in a local electric system is shown.

The law of distribution of solar power plant's generation for a certain time interval of the day during a year is analyzed. A mathematical model of SPP generation is proposed in the form of Gaussian mixtures. The basic characteristics of probabilistic nature of solar plant's generation are obtained. The possibility to coordinate solar plant's generation with daily consumption graphs is assessed. The probability of covering the given loadgraph by SEP generation during acertain time interval of the day throughout the year is determined.

The obtained probabilistic characteristics of the balancing process make it possible to determine the probability of ensuring the balance reliabilityby SPP generation in a set interval of the day.

Key words: generation power, solar powerplants, loading graph, Gaussian mixtures.

\section{Introduction}

Due to the fact that alternative and renewable energy sources are being developed in electric grids, the latter take signs of local electric systems (LES) [1]. This means that for them there areproblems that are typicalfor electric power systems (EPS) with large thermal, nuclear and hydroelectric power stations. These include the assurance of reliability of electric power supply to consumers, maintenance of voltage levels within permissible limits, optimization of power flows in orderto reduce losses, as well as maintenance of balance reliability in LES with combined electric supply from local and centralized sources of energy [2-4], as it is shown in Fig. 1.

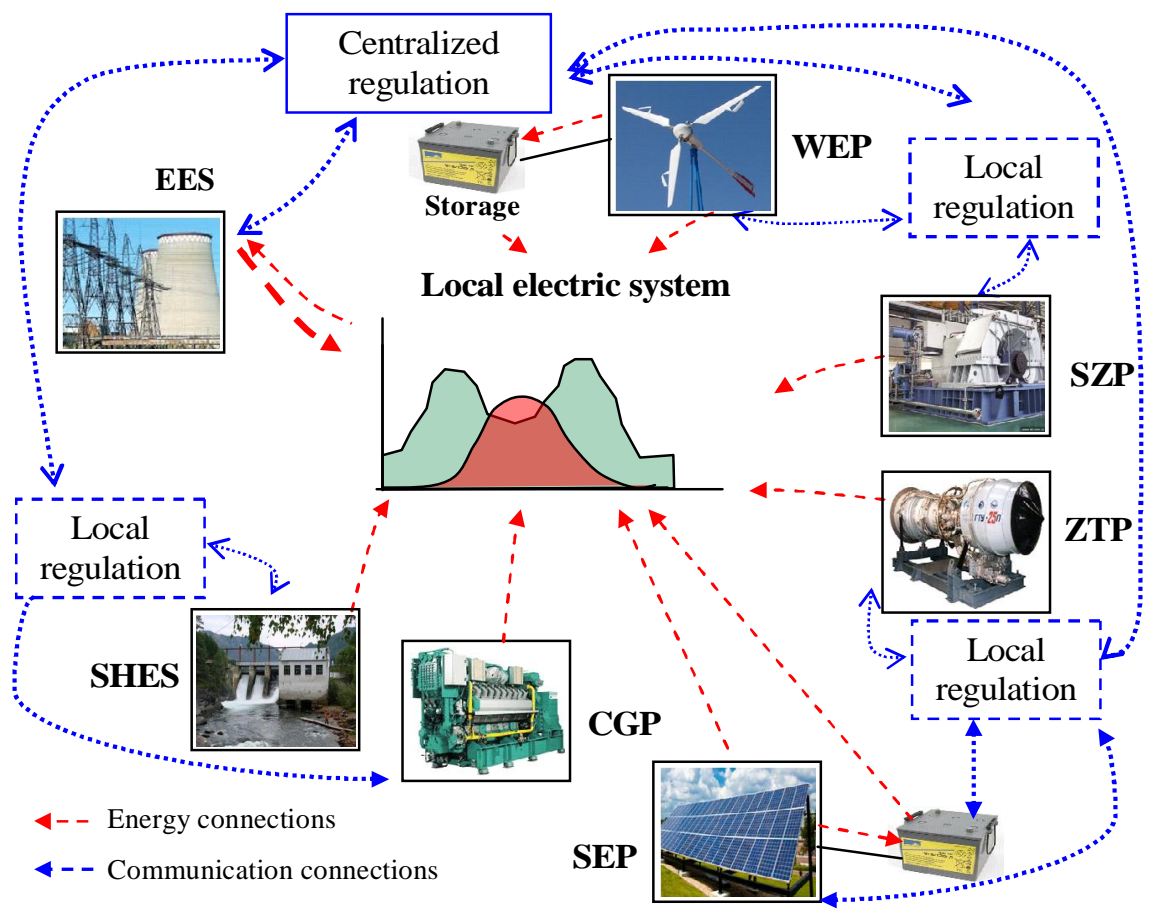

Fig. 1. Energy and communication connections of energy sources in SMART Grid EPS - Electric power system; $S P P$ - solar power plant; WEP - wind electric plant; SHES - small hydroelectric station; SGP and GTP - steam-gas and gas-turbine plants; CGP - cogeneration plant. 
Determining the priority of solving problems arising in LES, note the balance reliability as there liability of LES when its calculation model is determined by the balance of consumption and generation of electric energy, with the external supply being taken into account. The successful solution of other problems depends on the methods and means used to ensure the balance reliability. Technical and economic indices of LES depend on the balance of its active and reactive power [5]. The instability of RSE generation, in particular, by SPP and WEP, greatly influences the process of power balancing in LES. The instability of SPP and WEP generation is compensated by the power supplied to LES from EPS. As a result, the conditions of LES mode balancing influence the EPS modes. The optimization of LES and EPS's joint operationiswas considered in a number of research works [6-9]. The given paper considers the method of balance reliability assessment, which is based on the assessment of renewable source generation instability in the problem of covering the load graphof a local electric system. As the instability of WEP and SPP generation is of different nature, and, correspondingly, the character of its impact on electric energy balance in LES is also different, then they must be considered separately. The objective of the given paper is the development of an assessment method of SPP impact on the formation ofelectric energy balance in LES.

It is known [10] that RSE can be used in LES applying various criteria of optimality. Correspondingly, their participation in maintaining the balance of active and reactive power in LES is different. For instance, when optimizing a daily mode of RSE for the purpose of providing maximum operating revenues of their electric energy and minimizing electric power supply intended for consumers to LES from the electric energy market, EPS maintains the balance reliability. In this case, the task is to assess the instability of SEP and WEP generation and determine the EPS power reserve necessary to providethe balance reliability of LES. The role of SPP and WEP in maintaining the balance reliability is passive.

Another case is when, to provide the LES stability or underlimited possibilities of a centralized power supply system, it is necessary to influence the generation of energy sources in LES. In this case, a prior substantiated graph of their generation is set for RSE. There arises a task of RSE modes optimization in order to minimize the deviations from the set centralized schedule of their total generation $P_{R S E}(t)$ at the set limitations of primary energy resources and RSE characteristics [11]:

$$
\int_{t_{0}}^{t_{k}} \frac{1}{2}\left(P_{\mathrm{RSE}}(t)-\sum_{i=1}^{n} P_{i}(t)\right)^{2} d t \rightarrow \min ,
$$

where $P_{i}(t)$ - current values of RSE power in the time interval $t_{0} \div t_{k} ; n$ - the number of RSE involved in the RSE control.

The forecast information regarding weather parameters that is provided by the corresponding subsystem of an automatic control system (ACS) and enables the states of the controlled RSE to be rather adequately reproduced should be taken into account. Due to this, controlled and instable sources of energy such as WEP and SPP in efficiency functions and constraints of the problems of optimal control could be presented as a mathematical expectation of time dependences of generation $M_{W E P}\{P(t)\}, M_{S E P}\{P(t)\}, t \in\left[t_{0} ; t_{k}\right][12]$.
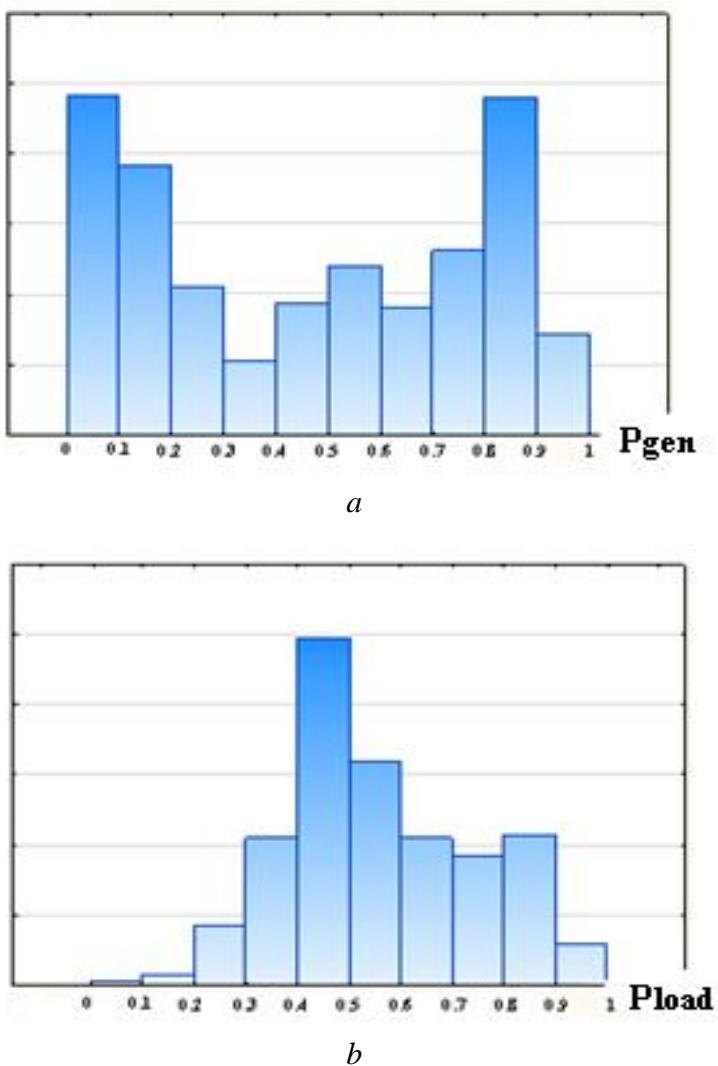

Fig. 2. Histogram of SPP annual generation (a), and histogram of annual consumption of electric energy $(b)$.

\section{Assessment of SPP generation stability}

Since the generation of electric energy by a solar powerplant greatly depends on the change in weather parameters and the duration of thelight day, it is expedient to analyzethe statistical data for each season. Fig. 2 shows, as an example, typical values of generation power $P_{\text {gen }}$ (Fig. 2, $a$ ) and load $P_{\text {load }}$ (Fig. 2, b), and recurrenceof these values during the year in relative units. The relative values of generation presented in 
Fig. 2, $a$ are reduced to the installed power of SPP, and the loading values in Fig. 2, $b$ are reduced to its maximum value. The histograms (see. Fig. 2, $a$ ) demonstrate several modes available in the sample.This shows the polytonality of SPP generation process. Such polytonality may be stipulated by the change in meteorological conditions in the place where the power station is located.

As in the given problem the distribution of a random statistical value could not be described by a single distribution law, it is suggested to use a Gaussian mixture of distribution. The probabilistic characteristics of the suggested mixture are assessed by the maximum likelihood criterion, applying the EM algorithm [13]:

$$
f(x)=\sum_{j=1}^{k} w_{j} f_{j}(x)
$$

where $f_{j}(x)$ - function of distribution density of $j$-th component of the mixture; $w_{j}$ - weight of $j$-th component of the mixture (priori probability), $\sum_{j=1}^{k} w_{j}=1, w_{j} \geq 0, j=1 \ldots k-$ number of the components in the mixture.

The function of distribution density has the form:

$$
f_{j}(x)=\frac{1}{(2 \pi)^{\frac{k}{2}}\left|\varsigma_{j}\right|^{\frac{1}{2}}} \mathrm{e}^{\left(-\frac{1}{2}\left(x-\mu_{j}\right)^{T} \varsigma_{j}^{-1}\left(x-\mu_{j}\right)\right)},
$$

where $\mu_{j}$ - mathematic expectation of $j$-th component, $\zeta_{j}$ - the covariational matrix of $j$-th component that has the content of root-mean-square deviation.

Likelihood functions belong to the parametric family of distributions $\varphi(x ; \theta)$ and are distinguishedonly by the values of the parameter $f_{j}(x)=\varphi\left(x ; \theta_{j}\right), \theta_{\mathrm{j}}=\left\{\mu_{\mathrm{j}}, \varsigma_{\mathrm{j}}\right\}$, with $\phi$ being a fixed function. In other words, to select the object $x$ from the mixture $f(x)$ means to select it from the distribution $f_{j}(x)$ with the probability $w_{j}$. The problem of splitting the mixture is solved when, having the sample $X^{m}$ of random values from the mixture $f(x)$, and knowing the number $k$ and the function $\phi$, it is necessary to evaluate the vector of parameters

$$
\stackrel{\mathrm{\Theta}}{\Theta}_{j}=\left(w_{j}, \theta_{j}\right) .
$$

The optimal quantity of components in the general model of Gaussian distribution mixture could be obtained by enumerating possible variants. At that, the problem is solved several times to provide agradual increase (decrease) ink values. A graph illustrating depencence of likelihood $\theta_{j \max }=\arg \max _{\theta} \sum_{x_{i} \in X^{m}} \ln \varphi\left(x_{i}, \theta_{j}\right)$ on $k$ is constructed, and the least value of $k$ at which the graph represents an abrupt jump of the likelihood (Fig. 3, $a, b$ ) is selected.

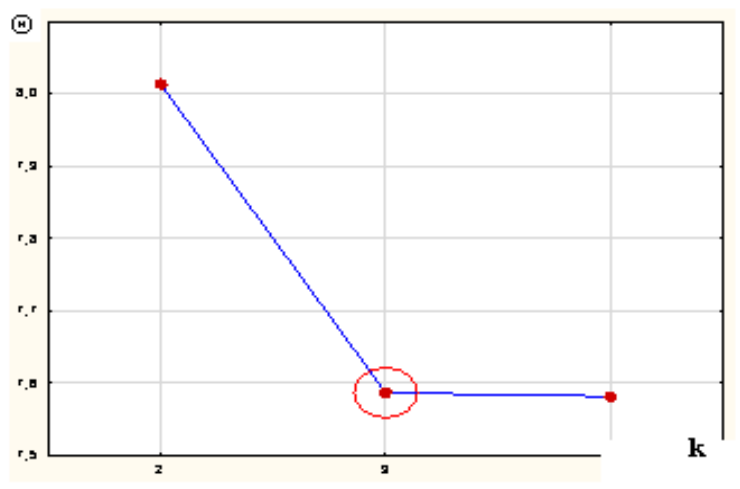

$a$

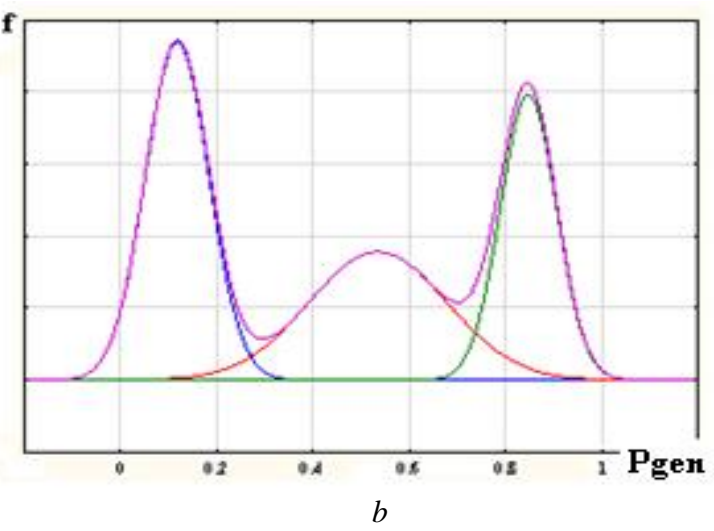

Fig. 3. Determination of the optimal number of components in the distribution mixture of SPP generation power $(a)$ and presentation of SPP generation power distribution $(b)$.

Let us illustrate the assessment of SPP generation stability on the basis of the statistical data regarding the generation in time interval from 12:30 till 13: 00 (Fig. 4) during the year.

The Kolmogorov-Smirnov criterion calculated for the suggested distribution shows the correspondence of theoretically suggested distribution toempirical data, as $75 \%$ of the empirical data correspond to the theoretically suggested law of distribution. In Fig. 4, a we can see that a three-component mixture of Gaussian distribution can ensure sufficiently accurate reproduction of a random value density. Having the basic probabilistic characteristics, it is possible to assess the probabilities both of covering and non-covering the electrical loads graph (ELG) by SPP generation. Fig. 5 shows the algorithm for the determination of probabilities to cover and not to cover the load graph by SPP generation. 


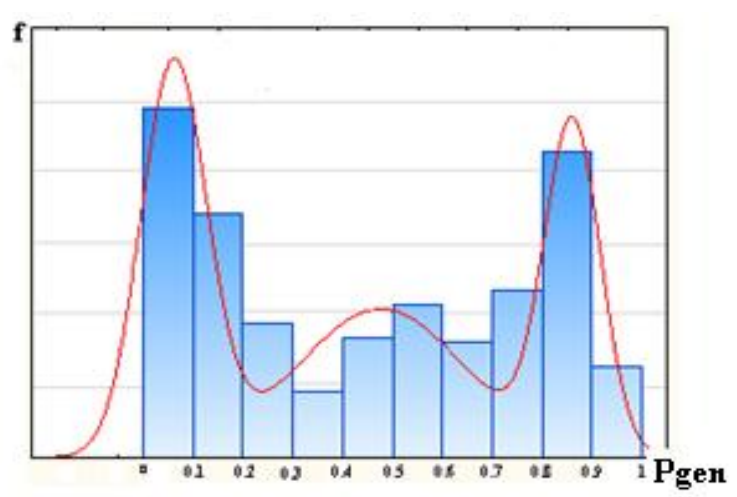

$a$

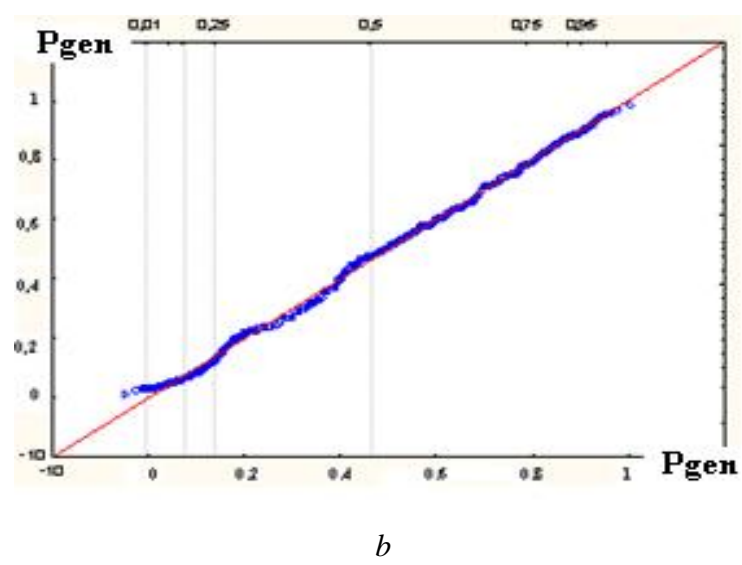

Fig. 4. Gaussian mixture that describes the law of SPP generation distribution (a), and quantile-quantile plot for the theoretically proposed law of distribution (b).
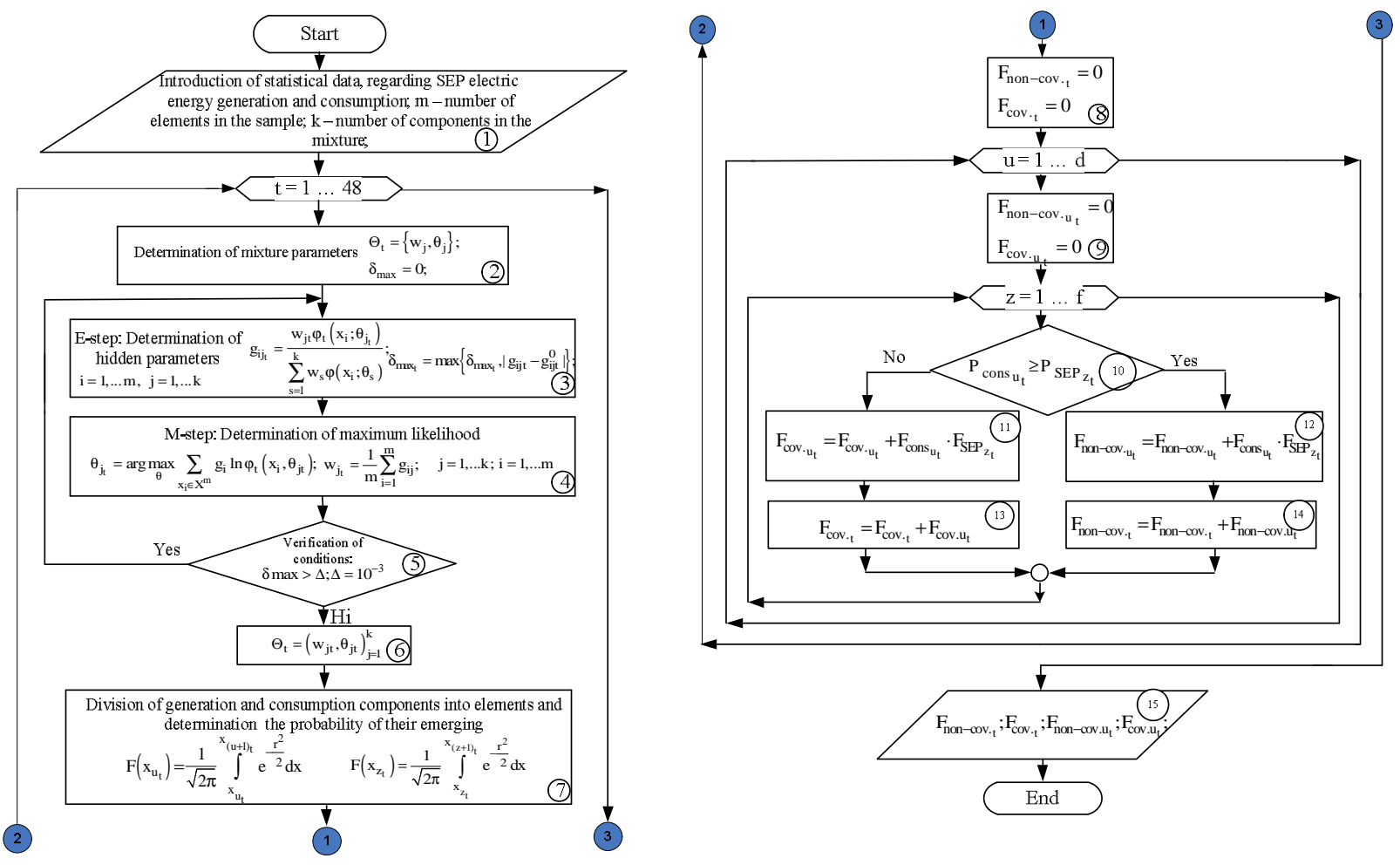

Fig. 5. Algorithm forthedetermination of probability of covering and non-covering the load graph by SPP generation

According to the EM algorithm (blocks 1-6), having initial data of generation and consumption processes (block 1), and initial approximation of mixtures parameters and a shutdown criterion (block 2), the parameters of Gaussian distributions mixtures (mathematical expectation, root-mean-square deviation and weight of mixture components) are determined. $g_{i j}=F\left(\theta_{j} \mid x\right)$, determined in block 3 , represents an unknown posterior probability of taking the sample from the $j$-th component of the mixture. Such probability can be determined applying
Bayes' formula. In block 4 , the optimal weights of mixture components $w_{j}$, are determined by the criterion of maximum likelihood. The iterative process stops when the value of the functional $Q(\Theta)=\ln \prod_{i=1}^{m} f\left(x_{i}\right)=\sum_{i=1}^{m} \ln \sum_{j=1}^{k} w_{j} f_{j}\left(x_{i}\right) \rightarrow \max (\Theta) \quad$ or the value of the hidden variables $G$ stop changing considerably (block 5). The obtained parameters of the distributions mixture of SPP generation and energy consumption (block 6) are decomposed, by 
means of the probability integral, into components with a certain step (block 7).

It should be noted that the less the step of mixture division,the higher the accuracy of calculation. Initial approximations of the probabilities of covering and noncovering the loading graph by the own generation of SPP are set in blocks 8,9 . If the element of the generation mixture component is greater than that of the electrical loading graph mixture (block 10), the probability of LG covering (block 11) and, correspondingly, LG non-covering (block 12) is determined. In blocks 13 and 14, the total probability of covering and non-covering the loading graph by SPP generation is determined. The probabilities determined in blocks 11-14 are deducedin block 15 .

It is obvious, that when SPP is used as a main source of power supply, it is expedient to speak only about

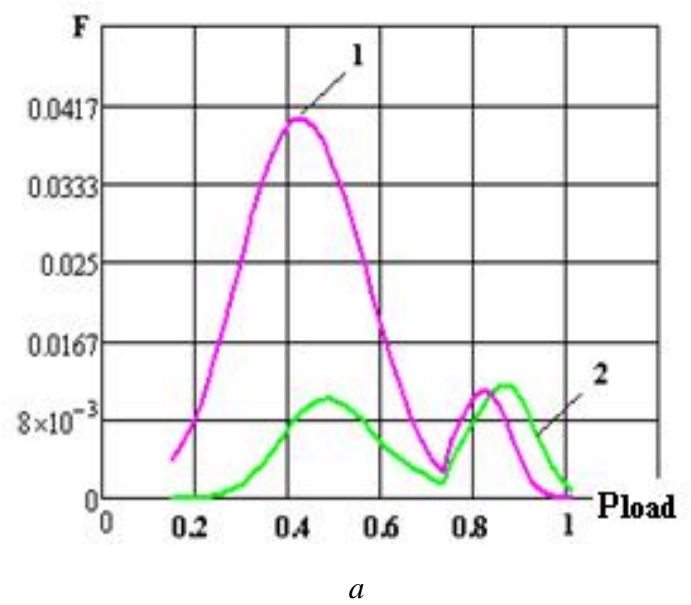

acertain probability of providing balance reliability both of an individual consumer and of a LES as a whole. Hence, there appears a problem of determining the power that is required to ensure the source of reserve. Sources of centralized electric supply [14] or storages of electric energy could be such a source.

According to the algorithm presented in Fig. 5, the probabilities of covering and non-covering the load graph by SPP generation are determined. In Fig. 6, the probabilities of covering (non-covering) the SPP loading graph in the time interval from 12.30 till 13.00 are given as an example. The minor probability of covering the loading graphis explained, besides natural conductions, by rather small installed powerof SPP. The probability of loading graph non-coveringis determined under the conditions when LES is also supplied from EPS.

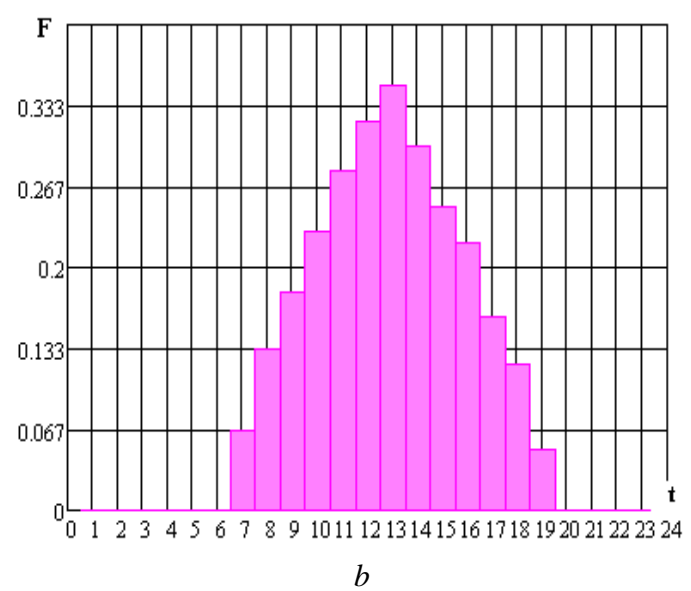

Fig. 6. Graphical representation of changing in probabilities: a - covering (1) and non-covering (2) the set consumption graph of by means of SPP generation in the 12: 30-13: 00 interval, $b$-covering the consumption graph during the day.

The probability of load graph covering enables usto determine a mathematical expectation of the redundant power, i.e. the power of SPP generation that is greater than the load in the $t$-th time interval of the day:

$$
\mu_{\text {red }_{t}}=\sum_{u} \overrightarrow{F_{\operatorname{cov}_{t_{u}}}} \cdot \overrightarrow{P_{\text {load }_{t_{u}}}},
$$

where $F_{\operatorname{cov}_{t_{u}}}$ - probability of load graph covering, $P_{\text {load }_{u}}$ - load power.

Similarly, we can determine the power to be provided by a storage or reserve source of centralized energy supply:

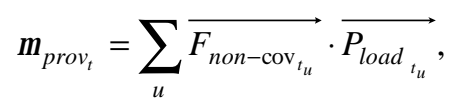

where $F_{n o n-c o v}{ }_{t_{u}}-$ probability of load graph noncovering, $P_{\text {load }}$ is the amount of deficit electric energy in the $t$-th time interval of the day. Hence, having the data regarding the surplus (5) and deficit of power (6), the probability of balance reliability provision by SPP generation inthe $t$-th time interval of the day can be determined. Mathematical expectation (5) will serve as input information for determining the capacity of an electric energy storage, and (6) will show what amount of electric energy must be provided by the reserve source.

\section{Conclusions}

The probabilistic characteristics both of the process of electric energy generation at solar power plants and of its consumption are quite accurately determined by means of the mathematical model developed on the basisof Gaussian mixture. Applying the obtained characteristics, it is relatively simple to obtain the probability of covering the load graph by the source of renewable energy and to determine the probability of balance reliability provision in a local electric system. It 
is expedient that the probability assessment of load graph provision be carried out at most on half-hourly basis.

This enables us to decrease the analysis errors stipulated by natural conditions of electric power generation by renewable sources and take into account the characteristic features of its consumption graphs.

\section{References}

[1] O. Kyrylenko, Y. Peterheria, T. Tereschenko, and V. Zhuikov, Intelligent systems of electric energy flows control in local objects. Kyiv, Ukraine: Media Press, 2005. (Ukrainian).

[2] P. Lezhniuk, A. Nikitorovych, O. Kovalchuk, and V. Kulyk, "Automation of distributed sources of electric energy operation in local electrical grid, based on SMART Grid concept". In Proceedings of the Institute of Electrodynamics of NASU. Collection of scientific papers. Special Issue, pp. 136-143, 2013. (Ukrainian).

[3] C. Borges and D. Falcao, "Optimal distributed generation allocation for reliability, losses, and voltage improvement", Int. J. Elect Power Energy Syst., vol. 28, no. 6, pp. 413-420, 2006.

[4] Q. Jiang, G. Geng, C. Guo, and Y. Cao, "An efficient implementation of automatic differentiation in interior point optimal power flow," IEEE Trans. Power Syst., vol. 25, no. 1, pp. 147-155, Feb. 2010.

[5] Intelligent electric grids: elements and modes, O.V. Kyrylenko, Ed., Kyiv, Ukraine: Institute of Electrodynamics of NASU, 2016. (Ukrainian).

[6] V. Popov, E. Yarmoliuk, and P. Zamkovoy, "Algorithm ofmulticriterial control of microgrids operation modes", East-European journal of advanced technologies, no. 2, p. 61-68, 2014. (Russian).

DOI: 10.15587 / 1729-4061.2014.23158.

[7] O. Kyrylenko O. Pavlovskyi, A. Yandulskyi, and S. Steliuk, "Operation control of electrical station with renewable sources of energy in conditions of frequency variations in electric system", Technical electrodynamics, no. 4, pp. 52-57, 2012. (Ukrainian).

[8] O. Yandulskyi, G. Trunina, and A. Nesterko, "Optimal voltage regulation in distribution electric grid with the source of distributed generation with the account of their belonging to one owner while using the reserve of active power", Bulletin of Kremenchuk Mykhala Ostrogradskyi National University, vol. 2, pp. 50-54, 2015. (Ukrainian) http://nbuv.gov.ua/UJRN/Vkdpu_2015_2_9

[9] O. Rubanenko, V. Lesko, "Optimal control of EES normal modes with the account of technical state of the transformers with LTC". In Proceedings of the
Institute of Electrodynamics of National Academy of Science of Ukraine. Special issue, pp. 154-161, 2013. (Ukrainian).

[10] O. Burykin, Y. Malohulko, "Optimization of operation mode of local elecrtical systems with renewable sources of energy", Proceedings of DonNTU. Series "Electrical engineering and power engineering”, vol. 15, no. 2, pp. 42-46, 2013. (Ukrainian).

[11] P. Lezhniuk, O. Kovalchuk, O. Nikitorovich, and V. Kulik, Renewable sources in distribution electric grids: Monograph. Vinnytsia, Ukraine: VNTU, 2014. (Ukrainian).

[12] NIST Releases Report on Smart Grid Development. National Institute of Standards and Technology (USA) - Recognized Standards for Inclusion. In Smart Grid Interoperability Standards Framework, Release 1.0 (Electronic resource).

http://collaborate.nist.gov/twiki-sggrid/bin/view/ _SmartGridInterim.

[13] S. Aivazian, V. Bukhshtaber, I. Eniukov, and L. Meshalkin, Applied Statistics: Classification and dimensionality decrease, Moscow, Russia: Finance and Statistics, 1989. (Russian).

[14] P. D. Lezhniuk, V. J. Komar, and S. V. Kravchuk, "Determination of optimal power of the reserve for provision of balance reliability of local electric system", Bulletin of NTU "KhPI" Series: New solutions in modern technologies, Kharkiv, Ukraine: NTU “KhPI”, vol. 1214, no. 42, pp. 69-75, 2016. (Ukrainian).

DOI: 10.20998 / 2413-4295.2016.42.11.

\section{ОЦІНЮВАННЯ БАЛАНСНОЇ НАДІЙ- НОСТІ В ЛОКАЛЬНІЙ ЕЛЕКТРИЧНІЙ СИСТЕМІ 3 НЕТРАДИЦІЙНИМИ І ВІДНОВЛЮВАНИМИ ДЖЕРЕЛАМИ ЕНЕРГІї}

Петро Лежнюк, Вячеслав Комар, Сергій Кравчук

Розв'язано актуальну задачу аналізу нестабільності генерування відновлювальних джерел електроенергії (ВДЕ), зокрема сонячних електричних станцій (СЕС). Показано вплив нестабільного генерування ВДЕ на баланс потужності в локальній електричній системі. Проаналізовано закон розподілу генерування сонячної електростанції для певного проміжку часу доби протягом року. Запропоновано математичну модель генерування СЕС у вигляді гауссових сумішей. Отримано основні характеристики імовірнісного характеру генерування сонячної електростанції. Оцінено можливість узгодження генерування сонячної електростанції 3 добовими графіками 
споживання. Визначено імовірність покриття заданого графіка навантаження генеруванням СЕС протягом певного часу доби впродовж всього року. Отримані імовірнісні характеристики процесу балансування дає змогу визначити ймовірність забезпечення балансової надійності генеруванням СЕС на заданому проміжку доби.

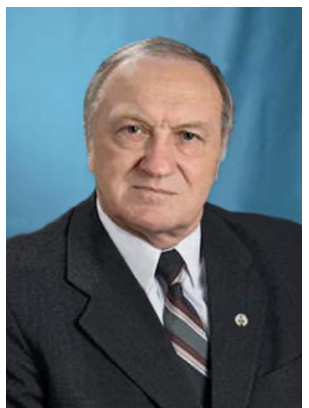

Petro Lezhniuk - D.Sc (Eng), professor, Head of Department of Electric Stations and Systems, Vinnytsia National Technical University, Ukraine. Long-time IEEE fellow. He has published over 420 scientific papers, developed a number of fundamentally new devices and software complexes for computers. These devices and programs are used

in electric power systems of Ukraine and Russia and give considerable economic effect. Main direction of scientific activity - mathematical modelling and optimization of electric power systems modes.

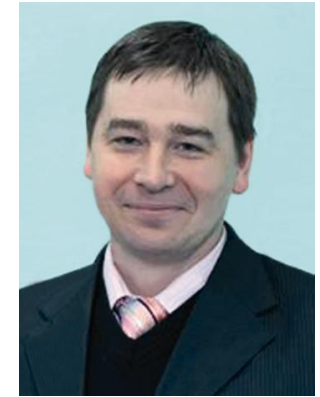

Viacheslav Komar - Ph.D. (Eng), assistant-professor, Department of Electric Stations and Systems of Vinnytsia National Technical University, Ukraine. He has published 35 scientific papers. Main direction of scientific activity automation of optimal control of electric power systems modes.

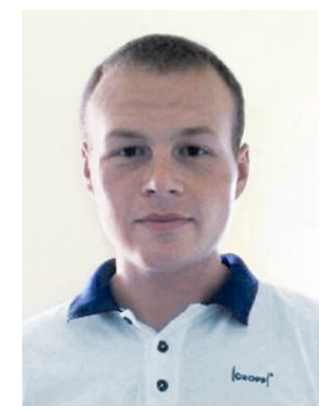

Serhiy Kravchuk - assistant, Department of Electric Stations and Systems of Vinnytsia National Technical University, Ukraine. He has published 8 scientific papers. Main direction of scientific activity - balance reliability in local energy systems with renewable sources of energy. 